\title{
The Effectiveness Of English Interactive Media In Teaching Writing (An Experimental Study Conducted For Eleventh Graders In Sma N1 Sedayu, Bantul Yogyakarta)
}

\author{
Atayewa Merjen Gurbangeldiyewna ${ }^{1}$, Hermayawati ${ }^{2}$ \\ English Education Department \\ Faculty of Teacher Training and Education \\ Mercu Buana University of Yogyakarta, Indonesia \\ email: ${ }^{1}$ merjenata88@mail.ru, ${ }^{2 h}$ ermayawati@yahoo.com
}

\begin{abstract}
The objectives of the study are to find out the ability of the students in writing descriptive text both before and after the treatment either at control group or experiment group; to find out the effectiveness of Interactive Media for teaching writing descriptive text; to find out what writing elements that received significant improvement after being taught by Interactive Media. This research was conducted using experimental study to overcome students' problem in learning English especially writing skill. The researcher used two classes as the subject: XI MIPA-1 as the experiment group and XI MIPA-4 as control group. Those MIPA classes belong to Argo Mulyo High School /SMA N 1 Sedayu, Argomulyo, Bantul.The experimental class was taught the descriptive text by using Interactive Media in the form of Macromedia Flash while control group was taught by using non-computer based lessons. Total sample of both classes were 60 students. The research was conducted within quasi-experiment study which used pre-post tests design of experiment and control groups. The researcher used this method in order to find out whether computer-based instruction/Interactive Media could make significant improvement on the students' descriptive writing skill. Such effectiveness was seen from difference of means between pre-post of both control and experiment groups and its $t$-test score at the degree of significancy. The $t$-test was higher than the $t$-table, Interactive Media then was proved significancy in improving the students' writing descriptive text skill. The students' writing was analyzed and scored based on rubrics postulated by Brown and Bailey including paragraph organization, its content, language structure, vocabulary and mechanics. The experiment shows that the $t$-test was (3.16) which is higher than $t$-table (2.000). The aspects of wtiting that has significant improvement were content, organization, structure, vocabulary - means pre-test of experimental group $=76.5$ and control group $=70.8$ increased into, experimental group $=87.22$ and control group $=78.8$ during post test with standard deviation of experimental group $=7.7$ and control group $=9.97$. Since there was a significant improvement of students' writing skill by using Interactive Media, this research then confirms that Interactive Media is effective for teaching writing at SMA level.
\end{abstract}

Key words: Macromedia Flash Player, Descriptive Text, Writing Skill, Quasi Experimental Researc. 


\section{Introduction}

The need of obtaining an effective teaching method for improving writing skill of Senior High School students in Indonesia is very important because their English writing ability is still low. It was revealed from a research done by Managing Basic Education of USAID in 2005 that writing ability of the Indonesian students is still insufficient. They only possess $15 \%$ of the writing techniques, $15 \%$ of the use of correct spelling, $15 \%$ of the correct writing devices, and $35 \%$ of the text's quality. Among four language skills: listening, speaking, writing and reading, writing skill is the most difficult one as it involves specific skills, such as: the choice of vocabulary, use of punctuation, structure of the sentence, organization of paragraph, the use of cohesive items, etc. Moreover, English as a foreign language for Indonesian students makes writing subject become more difficult for them. Students need to learn writing in order to be able to express their ideas, thoughts, and feelings in written language. In writing, the students will always deal with the process of expressing ideas into word, then into sentences, paragraph until they can create piece of writing (Prajayanti, 2012, p. 4).

I was interested to analyze register found on students ${ }^{\text {ee }}$ writings. So far I found that students disliked to write. This was due to the difficulties they found in its process (Maulina, n.d.). According to Harmer (2007: 265), speaking and writing are productive skill in which the students actually have to produce language on their own. It means that in writing a text, the students should be able to express their own ideas into word and sentence that grammatically correct and into a good essay format. Before writing their ideas, the students need to gather much information either by listening to other people, making conversation with others, or reading some books. Thus writing requires many language learning skills.

Such kinds of problems also happened at SMA N 1 Sedayu, Bantul, Yogyakarta. Those information were gathered by the researcher during her Classroom Teaching Practice (PPL) at SMA N 1 Sedayu, Bantul, Yogyakarta from July 09 to August 29, 2015. The researcher identified that the students' writing skill was still low, such as in the choosing of vocabulary, using of punctuation, structure of the sentence, organization of paragraph, the use of cohesive items, etc. Also their score was far from the targeted score/minimal criteria of the 2006 curriculum (it is called Kriteria Ketuntasan Minimal (KKM) with the minimal grade 75). The previous average score of sixty- four 
students of tenth grade at SMA N 1 Sedayu is 51,22 , so they could not reach the target score of 75 .

The researcher assumed that there were many causes of the writing skill weaknesses. It can be the detail instruction in the 2013 curriculum which did not mention the techniques of teaching writing skill. It can also be caused by learning tools or media for improving students' writing by other factors such as the innovation of the teacher, teaching facilities, or teaching media.

Realizing the complexity of writing skill problem, the researcher takes an action to implement new strategy in teaching writing skill because the researcher does not have any right to revise the curriculum, to train the teacher or to provide school facilities. Besides the reasons above, the researcher chooses "Interactive Media" as the learning and teaching media since the researcher believes that technology can motivate the students, help the teacher to animate the lesson materials, increase students' interest, and it has not been used by the teacher yet. It is also based on the library reviews that computer based media has been proved effective in teaching listening, reading, vocabulary, students' motivation, and grammar. (Nagata, 1998; Thorson,
2000; Liu and Reed, 1995; McNeil, 2000; Leppen).

Based on the background of the study above, the researcher formulates the statement of the problem as follows: (1) Does the use of Interactive Media improve the students' descriptive writing skill?; (2) What are the results of students' descriptive writing with and without Interactive Media?; (3) By referring to Brown (2000:369) writing rubrics, what writing elements do receive the most significant improvement?

Writing is the production of communication, linking ideas, and information development, or giving arguments to a particular reader or a group of readers (Hedge, 2005, p.10). Writing skill is very important to be learnt by students, because it requires good English structure, an ample of vocabularies, precise paragraph structure, types of text, etc. The students' writing can be in four types: descriptive, narrative, expository, and persuasive. (Gillie, Susan, and Mumford, 2001,p.15).

The research is primarily concentrated on descriptive text of eleventh grade students' at SMA N 1 Sedayu, Bantul Yogyakarta in the academic year 2015-2016. This research involves experimental group and control group that are selected 
purposively. Purposive sample means that all of the students available in the research setting were treated as the research subjects (Sugiyono, 2012, p. 124). The writing elements that are evaluated in the research consist of content, organization, vocabulary/ lexical, syntax / grammar and mechanic/ punctuation (Brown, 2000, p. 369). In order to reveal the improvement of the writing skill, the researcher needs also to limit the resources on the basic understanding of the writing theory, descriptive writing features, the use of media, and the effectiveness of Interactive Media as the teaching tool.

\section{Research Method}

This research was conducted using experimental study. According to Sugiyono (2012:107) experimental research is a kind of quantitative research which has certain characteristics such as having control and experimental groups.

The researcher used Quasi Experimental Research. This research involved experimental group and control group that were selected purposively (Purposive Sample). It means that all of the students available in the research setting were treated as the research subjects (Sugiyono, 2012, p. 124).
In this research the control group was treated writing lesson without using Interactive Media while the Experimental group had been taught by using Interactive Media. This experimental research was chosen to identify, analyze and describe about students' writing ability. Pre-test had been given before the students got the treatment while post- test had been given after the students got the treatment. Both of the pre- test and posttest results, then, were used to measure the students' ability.

Selection of the subject was very important steps in conducting a research study. There were two steps which had been discussed. The first was to determine the population and then to determine the sample.

Before collecting the data, the researcher made an instrument. Instrument was a tool or facility used by the researcher for collecting data. In this research the instruments were in the forms of questionnaire for need analysis, proto-type testing with pre- testing, and real implementation with post- testing.

\section{Sampling Technique}

$$
\text { According to Sugiyono }
$$

(2012:38) variable is an attribute

or activities which have specific variation. It was determined by the researcher to learn and conclude. Variable is 
the point of the research. This research

had two variables as follows:

Dependent Variable

Dependent variable in this research was the variable which was measured to find out the effectiveness of the other variable. That, dependent variable was "descriptive writing ability of the students".

Independent Variable

Independent variable was a variable that its variance influenced other variable. The independent variable of this research was "the Interactive Media".

\section{Data Collecting Technique}

Data Collecting Technique is systematically collect the information about target subjects or objects that involve in the research Kidder (1997). Collecting data was the most important activity in the research. There were some steps were taken by the researcher. They were as follows; (1) the researcher conducted pre-test; (2) the researcher gave post-test after three times of treatment for each group; (3) the researcher scored results of both preand post- tests by using Brown (2000: 369) writing rubric; (4) the results of their pre-and post-tests were compared.

\section{Data Analysis Technique}

According to Shamoo and Resnik (2003), data analysis technique is the process of systematically applying statistical technique to describe and illustrate, condense and recap, and evaluate data. In analyzing the data, the researcher used statistical analysis. By analyzing the student's score, the researcher identified and determined the degree of student's capability.

1. Scoring. The researcher gave score for the student's answer writing task. Writing Rubrics. Rubric is used widely in education to evaluate learning process. In scoring the students' writing assignment, the researcher also used the rubric postulated by Brown (2000: 369). The rubric categories the writing into four levels: excellent/very good, good/average, fair/poor, and very poor.

2. Statistical Analysis.To know how Interactive Media improved students' writing ability, the researcher analyzed the data from pre-post by using SPSS 20.

3. Categorizing. In this step the researcher categorized the student's score and the group them based on their achievement. The researcher 
wanted to know the student's achievement before and after giving the treatment. After getting the scores, the researcher categorized them into the following criteria:

Table 1. Categorizing

\begin{tabular}{lc}
\hline Score & Category \\
\hline $80-100$ & Excellent \\
$66-79$ & Good \\
$56-65$ & Fair \\
$40-55$ & Poor \\
$30-39$ & Very Poor \\
\hline
\end{tabular}

\section{Finding the significant differences by} using $t$-test

In this study $t$-test was used to know the difference in the result of teaching using Interactive Media to improve students' descriptive writing before and after giving the treatment (the result of pre-test and post-test).

To measure the significances of the pre-test and post-test the researcher used SPSS 20 for window with confidence interval of the difference is 95\% (0.05), significant two tailed (Sig. 2-tailed), and degree of freedom of 58 (n control $+n$ experiment-2). Manually, the $t$-test can be calculated by referring to Urdan (2010:95). The researcher gave interpretation $t$-test by comparing to $t$ table.

\section{Research Findings and Discussions}

\section{Need of the Students}

The results of need analysis show that among 32 students, more than half or $57.6 \%$ needed to practice writing skill with interactive media and $60.8 \%$ feel at ease when practicing writing with the aid of computer. In majority, the students really want to do some writing activities with the aid of computer because the students said that their teachers almost never use computer even the Interactive Media in teaching English. The students have initiated to fulfill their needs by visiting on-line resources and learned so much about writing essay or descriptive texts from free resources. They practiced their own learning strategy.

The teachers are challenged to create innovation to foster the students' writing skill in which the process of 
teaching and learning should be focused more on the activities such as writing good sentence, matching topic sentence with paragraph developer, or practicing punctuation with error identification. Moreover, the teachers are demanded to use computer-based media as the source of the writing object, place, and people. The picture of animation in computer assisted instruction is more vivid and real rather than printed picture.

\section{Research Result}

\section{Ability of the students in writing descriptive text before the treatment.}

The writing ability of the students at both class XI-MIPA1 (experiment group) and XI-MIPA4 (control group) before the experiment were quite the same

because the level of the vocabulary, syntax/grammar, the use of punctuation/mechanic, content, and essay organization were within the range of the same category. The ability of the students in using punctuation for example, both groups are still at the level of fair to poor since they have means score of 2.87 and 3.00. The students in this level frequently showed errors of spelling, punctuation, capitalization, paragraphing, poor handwriting, meaning confused or obscured. In the use of vocabularies, they have limited range, frequent errors word/idiom form, limited choice of words, wrong usage but meaning not obscured. Thus, their vocabularies comprehension was at the level of average.

By referring to Brown's writing evaluation (2000), it is implied that both classes have different starting point but belong to the same category. Control class, for instance, has means of 70.83 and experiment group's means is 76.5 but they are still in the category of good (range 70-79).

Theoretically, it can be implied that the sample taken in this research (the students at class XI-MIPA 1 and XI MIPA 4) are almost homogeneous in their basic skill of writing descriptive essay. This phenomenon is not strange because they still belong to the same high school. Perhaps they have been taught by the same teacher within the same semester.

From the score of pre-test both control and experiment groups, it can be interpreted that they had the same difficulties in mastering vocabulary, syntax, and mechanic of good descriptive writing. Such difficulties have been also identified by previous researches (Hedge, 2005; Kellogg, 2008; Prajayanti, 2012) that writing is a major cognitive challenge because it is at once a test of memory, language, and thinking ability. 
In writing descriptive text the students should be careful with the choice of words/vocabularies, correct usage of adjectives, structure, punctuation, etc. In descriptive text, the students should depict the object, person or place by using verb of perceptions such as seems, hear, taste, feel, see, smell, touch, etc. They should be able to focus on the unique qualities of a person, object, or thing (Wyrick,2011;326).

\section{Ability of the students in writing descriptive text after the treatment.}

Interactive Media as the learning and teaching media had been used for motivating the students, helping the teacher to animate the lesson materials, improve student's descriptive writing skill. It is based on the library reviews that computer based media has been proved effective in teaching listening, reading, vocabulary, students' motivation, and grammar (Nagata, 1998;
Thorson, 2000; Liu and Reed, 1995; McNeil, 2000; Leppen).

The effectiveness of Interactive Media in teaching descriptive text has been tested by the researcher. It is clearly seen in Table 2. that Interactive Media has brought different results of descritive writing skill of the experiment group. It has higher means score (87.22) compared to non- Interactive Media class (control class means $=78.83)$. Among 30 students at the experment class,there are 26 students reached excellent category and 4 students achieved good category. No students at the level of poor or fair. The results are so different from those of control group which has 2 students at fair level and 1 student at poor level. Control group results are not so much different fromits pre-test.

\section{Table 2. Results of Post-test Experiment and Control Groups}

\begin{tabular}{lll}
\hline $\begin{array}{l}\text { Descriptive } \\
\text { statistic }\end{array}$ & $\begin{array}{l}\text { Post-test } \\
\text { Control }\end{array}$ & $\begin{array}{l}\text { Post-test } \\
\text { Experiment }\end{array}$ \\
\hline Mean & 78.83 & 87.22 \\
Median & 80.0 & 90 \\
Mode & 85.0 & 95 \\
Mean Deviation & 1.82 & 3.2 \\
Std.deviation & 9.97 & 7,7 \\
Excellent category & 17 students & 26 students \\
Good category & 10 students & 4 students \\
Fair category & 2 students & 0 students \\
Poor category & 1 student & 0 student \\
Content & 22.7 fair & 25.53 good \\
Organization & 17.3 good & 18.47 excellent \\
\hline
\end{tabular}




\begin{tabular}{lll}
\hline Vocabulary/Lexical & 16.2 good & 18.10 excellent \\
Syntax/Grammar & 19.5 good & 21.70 excellent \\
Mechanics/Punctua & 3.1 fair & 3.43 fair \\
tion & & \\
\hline
\end{tabular}

Writing elements that received significant improvement after being taught by Interactive Media.

In term of students competence in writing good descriptive text with good organisation,corret structure, good choice of vocabularies, the experiment groups indicate very significant progress. It is seen from the mastery of syntax, vocabularies, and essay organisation. When their ability is at excellent level, it means that the students have fluency expression; ideas are clearly stated/supported, succinct, well organizes, logical sequencing, and cohesive. Their sentence structures are very good because they use complex construction, few errors of agreement, tense, number, word order/function, articles, and pronoun. Nevertheless, they still get problem with punctuation or mechanic because they are not careful with spelling, punctuation, capitalization, paragraphing, poor handwriting, meaning confused or obscured.

\section{Hypothesis Testing Result}

From the findings and discussions above, it can be inferred that there was a significant difference between the descriptive writing of the students who were taught using Interactive Media and those who did not use Interactive Media. The first evidence can be seen from means score of pre and post test of both groups. Post-test means score of experiment group is 87.22 while control group is only 78.83 with mean deviation 3.2 and standard deviation of 7.7 which indicates the differences between pre and post test score. The second indicator is the value of $t$-test. From the results of SPSS output of Independent sampletest, it is found that the score of $t$-test is 3.161 which is higher than the $t$-table (2.000) with $95 \%$ level of reliability or $5 \%$ 
level of significance $(0.01<0.05)$ and $\mathrm{df}=58 \quad\left(\mathrm{n}_{1}+\mathrm{n}_{2}-2\right) . \quad$ It means that the significant score or sig. (2-tailed) is less than 0.05. Therefore, it can be concluded that there is a significant differences of students' progress in writing descriptive text by using Interactive Media or it can be said that the null hypothesis (Ho) is rejected and the working hypothesis $(\mathrm{Ha})$ is accepted. The accepteance of the working hypotheis is in line with the Warschauer (1999) research results that ComputerBased teaching materials have significant contribution to the Intermediate ESL class at University of Hawaii. By using real time and internet connection, they can gain additional writing materials and excercises in classs. Moreover, they can do collaboration learning.

Since there is a significant improvement of students' writing skill by using Interactive Media, this research then confirms the effectiveness of Interactive Media for teaching writing at SMA level as Muhrodin(2011),Wardani (2013), and Zarkoni (2014) had conducted similar research at SMP level.

\section{Conclusion}

Related to the above findings, it was clearly seen in Table 2. that Interactive Media has brought different results of descriptive writing skill of the experiment group. It was effective in teaching writing descriptive text. It can be seen from statistical analysis of this study, the group that had been taught using Interactive Media get higher means score (87.22) compared to nonInteractive Media group (control class means $=78.83$ ). Among 30 students at the experment class, there were 26 students reached excellent category and 4 students achieved good category. There was no students at the level of poor or fair. The results were so different from those of control group which has 2 students at fair level and 1 students at poor level. Control group results were not so much different from its pre-test.

\section{Recommendation}

In line with the conclusion previo usly stated, the researcher would like to give suggestions to:

1. English teachers

English teachers are suggested $t$ $o$ be creative and innovative in designing the lesson materials in order to improve writing skill of the Senior High School (SMA) students. The teachers should use Computer Media or Computer Assisted Insruction/Computer Assisted Language Learning or software for designing multimediabased /animation-based lessons. As it 
has been proved from previous

research and this research that Interactive Media-based is effective to improve desriptive writing skill of the students.

2. SMA students

The students should be happy that Interactive Media-based course are effective in improving desriptive writing skill but they should not keep the spoon feed habit in learning. They should play active role and increase their enquiry for getting new language learning.

3. Further researcher

The results of the study are very useful for future researcher in Teaching of English as Foreign Language (TEFL) or the Teaching of English as Second Language (TESOL) in Indonesia and Turkmenistan. The use of computer software as instrument for upgrading the students' language skill should be shared into other areas of especially such as grammar, vocabulary building, pronunciation, and animation for teaching articles, etc.

\section{References}

Brown, Douglas H. 2000. Teaching by Principles. $\quad 2^{\text {nd }}$ ed. Cambridge: Pearson. Longman.

Gillie. Susan, Mumford. 2001. "An Integrated Course for Native Speaker of English". Singapore: McGraw Hill.
Harmer, Jeremy. 2007. The Practice of English Language Teaching. $4^{\text {th }}$ ed. London: Longman.

Hedge T. 2005. Writing. New York: Oxford University Press.

Kellogg, Ronald T. 2008. Training Writing Skill: $A$ cognitive Developmental Perspective. Journal of Writing Research. USA: Department of Psychology, Saint Louis University.

Kidder, L., and Fine, M. 1987. Qualitative and Quantitative Methods: When Stories Converge. Multiple Methods in Program Evaluation. New Directions for Program Evaluation. No. 35. San Francisco, CA:Jossey-Bass.

Leppenen S, Paula K.1995. Experimenting With Computer Conferencing in English for Academic Purposes. ELT Journal. 49 (1), 26-36.

Liu M, Reed W. M. 1995. The Effect of Hypermedia-Assisted-Instruction on Second Language Learning. Journal of Educational Computing Research, 12(2), 159-175.

Maulina, A. E. (n.d.). Register Realization in the Writing of 8 th Grade Students of SMP Kesatrian Semarang ( A Comparative Study between Dialogue and Recount Text ). JELE, 1, 1-15. Retrieved From http://ejurnal.mercubuanayogya.ac.id/index.php/jele/article/ view/13

McNeil, Aurelia. 2000. ComputerAssisted Instruction: It's Value to Second Language Learners. Eric Digest. No. ED 444365.

Muhrodin, Ultivatun. 2011. Improving the Process of Teaching and Learning Speaking Through Macromedia Flash Animation. Yogyakarta: Undergraduate Thesis. UIN. Avaiblefrom: http://eprints.uny.ac.id/21061/1/Ultiv atun $\% 20$ Deka $\% 20$ Ocvaliana $\% 20 \mathrm{M} \%$ 2007202244133.pdf

Nagata N. 1998. Input vs. Output Practice in Educational Software for Second Language Acquisition. 
Language Learning and Technology, 1(2), 23-40. Reviewed. August Available from: http://llt.msu.edu/vol1num2/article1/ default.html. Journal.

Prajayanti, Isna. 2012. Knowladge of Genres: Improving Students Writing Ability in English. Available from

https://isnanamaxu.wordpress.com/20 $12 / 06 / 26 / \quad$ knowladge-of-genresimproving-students-writing-abilityin-english/. [Accessed 26 June 2012].

Shamoo, A.E., Resnik, B.R. 2003. Responsible Conduct of Research. England: Oxford University Press.

Sugiyono. 2012. Metode Penelitian Kuantitatif Kualitatif dan $R$ \& B. Bandung: Alfabeta.

Thorson H. 2000. Using the Computer to Compare Foreign and Native Language Writing Processes: A Statistical and Case Study Approach. Modern Language Journal, 84(2), 155-170.

Urdan, Timothy C. 2010. Statistics in Plain English. London: Santa Clara University.
Wardani, Ratna K. 2013.Using Flash Animation to Improve Students, Learning Behaviors in Speaking Class Particularly in Retelling Story. Undergraduate Thesis. Available from: http://lib.unnes.ac.id/17077/1/22 01406565.pdf.

Warschauer M. 1999. Electronic Illiteracies: Language, Culture, and Power in Online

Education. Hillsdale, NJ: Lawrence Erlbaum Associates.

Wyrick, Jean. 2011. Steps to Writing Well: With Additional ReadingEight Edition. Boston: Wadsworth. Available from:https://pakpuguh.wordpress. Com /2011/08/12/descriptiontext/. [Accessed 12 August 2011].

Zarkoni. 2014. The Use of Macromedia Flash to Increase Vocabulary Mastery. Undergraduate Thesis, UPI, Bandung. Available from:

http://perpus.iainsalatiga.ac.id/d ocfiles/fulltext/090b2e5979dfc4e f.pdf 